\title{
DISCUSSION
}

\section{CONTEMPORARY TRANSFORMATIONS OF ETHNOLOGY/ANTHROPOLOGY IN RUSSIA: AN INVITATION TO FURTHER DISCUSSION}

\author{
Dmitriy Funk \\ Professor and Chair, Department of Ethnology, Moscow State University \\ Chief Researcher, Tomsk State University, Russia \\ e-mail:d_funk@iea.ras.ru
}

\section{Irina Nam}

Professor, Department of Russian History

Head of the Laboratory for Social and Anthropological Research

Tomsk State University, Russia

e-mail: namirina@bk.ru

\section{INTRODUCTORY REMARKS}

Exactly two years ago, in the 63rd volume of Folklore: Electronic Journal of Folklore, our colleagues Aimar Ventsel and Natalia Struchkova published their reflection on some of the many problems that exist in the post-Soviet academic anthropology - among them the problem of relationships between academic traditions and academic writing culture (Ventsel \& Struchkova 2016: 121-126). Here we would like to continue this discussion and elaborate on a few other issues which are, in our view, characteristic of anthropology in Russia in the first place but also in other countries of the post-Soviet space. ${ }^{1}$

The breakaway from old paradigms of Soviet/Russian ethnography and its academic language coincided in time with the dissolution of the USSR and was unambiguously marked within the discipline by renaming of the main and, in fact, only ethnographic academic journal available at that time: in 1992, Etnograficheskoe obozrenie (Ethnographic Review) replaced Sovetskaia etnografiia (Soviet Ethnography). Coincidentally or not, the new title alluded to the possibility of the continued presence of ethnography in post-Soviet Russia, with an indispensable return to the evolutionary paradigm that existed a hundred years ago (Etnograficheskoe obozrenie had already been issued in Russia in the period from 1889 to 1916). Luckily, the reality turned out to be 
different, and the title Etnograficheskoe obozrenie proved to be, as it seems, just an indicator of the then confusion among Russian researchers and hence their attempt to regain confidence in the future through returning to the 'roots'. Also indicative in this regard is the fact that in 1992-93 practically each issue of the renewed journal contained in its special section titled "Reflection on the discipline's future" a dozen of utterly thought-provoking articles that criticized or defended the previously applied approaches, and offered thoughts on the history of the discipline and the fate of researchers in it along with predictions about the future of ethnography (Tishkov 1992: 5-20; Basilov 1992: 3-17; Markov 1992: 3-7; Shnirelman 1992: 7-18; Kon 1993: 3-8; Arutiunov 1993: 8-14; Sokolovskiy 1993/2: 3-13; 1993/3: 3-14).

It is rather interesting to explore the way this discussion further unfolded. As regards Etnograficheskoe obozrenie, some articles on this topic reappeared in it only in 1994 and 1996; afterwards, the section "Reflection on the Discipline's Future" (whose very title started to induce sadness) was turned into a more neutral "Issues of theory and methodology" or "Issues of theory", although it occasionally featured publications on research questions and traditions in Russian ethnography (see, for example, Semenov 1998: 3-17; Basilov 1998: 18-45; Karlov 2000: 3-21).

The reflection on 'the discipline's future', which varied thematically and in terms of the language used and happened to sporadically occupy the journal's pages also after the year 2000 , has, since 2005 , completely disappeared from Etnograficheskoe obozrenie. It was in that very year that some old sections were excluded from the journal, and an approach was adopted to publish the journal's special issues edited by guest editors. That turn, in our opinion, has radically changed the journal itself and the way anthropology was and is viewed in Russia. This, however, does not mean that thinking about the history and future of ethnography was neglected. Not at all. On the one hand, the understanding of the discipline changed, widened to what it was and is elsewhere, and, following their European and American counterparts, many Russian researchers started to call it anthropology, only at times narrowing this name down to social or cultural anthropology. On the other hand, the reflection referred to above also remained. It is just that it was extended to cover similar issues raised in the field of anthropology outside Russia (Elfimov 2005: 4-101; Elfimov 2012), and also, this kind of reflection on the fate of Russian ethnography (ethnology/ anthropology) would appear more often in other Russian journals - those on culturology and history (Tishkov 2002: 3-18; Sokolovskiy 2003: 136-159; 2009: 45-64; 2011: 70-89; Tishkov \& Pivneva 2010: 3-21; Funk 2014: 93-102).

Many aspects of the transformation processes in ethnography (which in most cases started to be called 'ethnology' or even 'anthropology' in the post- 
Soviet academia's language) have already been considered in detail. Below, we would like to discuss only three cases which seem worthy of attention in terms of identifying significant transformations or, conversely, revealing a lack of any noticeable progress over the last two and a half decades. These include the issue of developing high-quality BA and MA programmes at universities, the non-availability of textbooks / specialized collections (and of the very access to contemporary research literature in the field), and the lack of high-quality specialized journals. We believe that the speed and quality of further changes in Russian anthropology will largely depend on whether or not these issues will be tackled successfully, if at all.

First of all, the term 'anthropology' itself should be commented upon on our part. The quiet revolution that Etnograficheskoe obozrenie experienced in 2005 finally resulted in the fact that the journal has, 'by default', adopted a new understanding of anthropology as a research area without any debates or battles over the 'necessity' to retain and accentuate ethnicity-related themes (that were, in fact, imposed on researchers by the very term 'ethnography' or 'ethnology').

Below, in our discussion about anthropology, we use the common understanding of the structure of this social discipline comprised of the so-called Boas tetrad: 1) social, cultural or socio-cultural anthropology; 2) linguistic anthropology; 3 ) biological or physical anthropology; and 4) archaeology. However, it should be noted here that such an understanding is far from being shared by all our colleagues and that even the so-called 'passport of the specialty of ethnography, ethnology, and anthropology' (available on the website of the Higher Attestation Commission of the Russian Federation) presents the discipline as it used to be seen in the USSR thirty or, rather, forty years ago - with references to ethno-genesis, classic descriptive ethnography, ethnic history, and ethnological regional studies as the first (and most important?) of the possible research foci. ${ }^{2}$

\section{DESCRIBING ANTHROPOLGY AT UNIVERSITIES}

Starting with ethnological/anthropological education at Russian universities, it should be said that it is the most significant aspect when it comes to assessing the state of anthropology, as universities are the places where one has the opportunity to develop interest in a given discipline as well as analytical skills, which will then allow some of the students to become researchers (including at universities themselves), employees of government bodies, museum workers, experts working in the media, at various foundations, and consulting agencies.

During the recent Soviet past (the post-war period), dealing with ethnography in the Russian Soviet Federative Socialist Republic (RSFSR) was quite 
easy: there were specialized departments at the Moscow and Leningrad State Universities and later on, beginning in 1985, at Omsk University as well - all three being part of the respective history faculties. Practically all of the first decade following the collapse of the USSR was the time when former staff from faculties of philosophy and sociology was searching for their place under the new and extremely difficult socio-economic conditions. In the 1990s and, probably, in the first half of the 2000s as well, complete confusion reigned in Russia in relation to the content of old and new educational programmes whose titles contained the terms 'ethnology', 'social anthropology', 'cultural anthropology', and 'philosophical anthropology'. These programmes would often (or even, as a rule) be run by Russian colleagues with no specialized education in ethnology. However, already in the first decade of the 21st century, at least at two universities the situation gradually started to change for the better. The ethnological faculty of the European University at Saint Petersburg and the Study and Research Centre of Social Anthropology (SRCSA) at the Russian State University for the Humanities (Moscow) pioneered the radical change in educational standards in social and cultural anthropology.

Thanks to the efforts undertaken by Valeriy Tishkov, Director of the SRCSA (and for a long time Director of the Institute of Ethnology and Anthropology of the Russian Academy of Sciences in Moscow), and Olga Artemova, Deputy Director of the SRCSA, federal state educational standards for the subject area "Anthropology and ethnology" were developed and introduced: in March 2010 for master programmes and in November 2011 - for bachelor programmes. There seemed to be only one step left to be made from these educational standards toward their implementation through elaboration of quality BA and MA programmes, creation (or re-training) of specialized departments, centres, and laboratories, and, finally, allocation of state-funded places at universities that could be viewed as a kind of social order for specialists on the part of the state. In the end, this step was made by the Faculty of Anthropology ${ }^{3}$ at the European University in Saint Petersburg - in the form of a master programme introduced here - but also by the Department of Ethnography and Anthropology at the Institute of History at Saint Petersburg State University, ${ }^{4}$ by the Department of Archaeology and Ethnology ${ }^{5}$ of the Institute for the Humanities and Arts, the Department of History at the Ural Federal University, ${ }^{6}$ by the Far Eastern Federal University (it is called here "Anthropology of Asia-Pacific region"7); by the SRCSA at the Russian State University for the Humanities in Moscow ${ }^{8}$ within both bachelor and master programmes - and by the faculties of history of Kazan (Privolzhie) Federal University (Department of the History of Tatarstan, Archaeology, and Ethnology) ${ }^{9}$, of Omsk State University (Department of Ethnology, Anthropology, Archaeology, and Museology $)^{10}$, and, starting from 
2015, of Tomsk State University (Laboratory for Social and Anthropological Research, http://lsar.tsu.ru/en//) ${ }^{11}$.

It would not be right to state that the abovementioned university centres for educating anthropologists/ethnologists, as well as the subject area of "Anthropology and ethnology" as such, are the only and best ones in Russia today. There is, for example, a quite well-developed and professionally run master programme on social anthropology at the Department of Cultural Anthropology and Ethnic Sociology (Faculty of Sociology) of Saint Petersburg State University. ${ }^{12}$ As for the country's largest university - Lomonosov Moscow State University - for many decades, two faculties have been educating specialists in anthropology here: the Faculty of Biology (Department of Anthropology), ${ }^{13}$ where students specialize in general anthropology, anthropogenesis, human morphology, and ethnic anthropology; and the Faculty of History (Department of Ethnology), ${ }^{14}$ which offers specialization in sociocultural anthropology.

For the sake of justice, it should be noted that educational programmes titled "Anthropology and Ethnology" do exist at a few other Russian universities (e.g., a master programme implemented in 2013 at the Department of Philosophy and History of Science, Faculty of Art History and Intercultural Communication, at Belgorod State Institute of Arts and Culture ${ }_{2}^{15}$ or at the Department of Social Anthropology and Ethnonational Processes, Faculty of Philosophy, at Orlov State University named after I.S. Turgenev, ${ }^{16}$ but it is rather difficult to say how these programmes as well as the staff of these departments (who are candidates and even doctors of pedagogical, philosophical, agricultural, and, more rarely, historical and other sciences) are connected with sociocultural anthropology. At a number of universities, there are departments of different anthropologies (philosophical, psychological, pedagogical, and other) whose relationship with sociocultural and/or biological/physical anthropology is, for the most part, equally unclear.

There are no centres of linguistic anthropology in Russia yet, with the exception of the Laboratory of Linguistic Anthropology, established at Tomsk State University in 2017, and a series of lectures delivered on this subject area in bachelor and/or master programmes at the Department of Ethnology of the European University at Saint Petersburg, as well as Lomonosov Moscow State University.

One of the greatest challenges facing the introduction of quality education and training in anthropology/ethnology is that the discipline is being predominantly affiliated with the history faculties/departments - the fact that does not allow students to start specializing in anthropology/ethnology during the first two years of study. We will not go into the long-held dispute over the benefits (or absence thereof) of teaching history to students of anthropology in Russia, 
but only note that viewing ethnology as a historical discipline keeps ethnology anchored in the arts and humanities, whereas anthropology in the broad sense that we elaborated upon above belongs to the social sciences. Having gained hands-on experience in educating ethnologists at the history faculties of Russian universities, we can confidently argue that trying to enrich a bachelor programme with a variety of lectures and practical classes needed for proper education and training of anthropologists is simply impossible in the current situation for at least one reason - at history faculties, only semesters from the fifth to the seventh are allocated to specialization in ethnology per se, with the eighth semester being a concluding one and thus better left for students to write their (bachelor) qualification theses.

Another, no less important, issue is that of university teacher training and development. However attractive the names and even the content of syllabi may be, a good impression of educational programmes can easily be spoiled by the lack of adequate competency on the part of the teacher. Most of the specialized (in anthropology) faculties do not have faculty members with special international anthropological training, either Russian nationals or specialists invited from abroad. Also, the educational programmes available either do not offer or barely ever offer important lecture courses in Western European languages. In the past four to five years, anthropological courses seem to have regularly been taught (in English) at two Russian universities only: at the Department of Ethnology, Lomonosov Moscow State University (courses: "American Indians: Histories and cultures", "Developing and managing applied anthropology projects", "The anthropology of space", "Tribal peoples in the modern world" by Professor Andrew Wiget, and "Anthropology of migration" and "Anthropology of childhood" by Dr. Elena Khlinovskaya Rockhill), and at the Laboratory for Social and Anthropological Research, Tomsk State University (courses "Ethnology, French style: The 20th century" by Professor Otto Habeck, "Modern approaches in anthropological studies of religion" by Dr. Agnieszka Halemba, "Introduction to the anthropology of music" by Dr. Ioannis Tsioulakis, and some others).

\section{WHAT AND WHERE TO READ?}

While discussing university education and training in anthropology, we cannot but turn to the issue of educational and research literature as well. One could wonder what kind of a problem there is with the literature when it comes to textbooks, for example. However, it is this overreliance on textbooks, where 'everything about everything' is presented to students in a condensed way, that causes difficulty for the development of anthropology as a social science. 
We cannot say to either the society as a whole or to some part of it: "Halt! I am going to describe you now". Textbooks on anthropology can be (and are) compiled, based on two main principles: description of static phenomena, referring, as a rule, to the period of the late nineteenth to the early twentieth centuries (in other words, describing something that ceased to exist long ago, and often doing so in a research language that could be seen as characteristic of colonial ethnography) or introduction to a certain theme drawing on collections of works comprised of best anthropological research writings. With very few exceptions, of the two only the first principle applies to Russia.

Nevertheless, as regards the introduction to anthropology, thanks to the efforts of colleagues from the Institute of Ethnology and Anthropology (Russian Academy of Sciences) and the Higher School of Economics, students have been presented with two remarkable textbooks over the recent time, namely, Social Anthropology: Investigating Human Social Life by Alan Barnard (2009) and What is Anthropology? by Thomas Hylland Eriksen (2014). Where does the problem lie then? We think in the very language in which contemporary anthropology is written.

In relation to the collections of works mentioned, this means that these either need to be read in the original (in a foreign language) or be translated into Russian. The second option is possible but difficult to realize due to the enormous volume of such collections out there, let alone the necessity to obtain permission from publishing houses to translate these texts. Such collections are indeed numerous; Wiley-Blackwell alone has published a few dozens of textbooks/readers in social and cultural anthropology, ${ }^{17}$ and this publishing company is far from being the only one actively issuing collections of the kind. Alas, Russian colleagues have little to offer in this regard - no readers, either of their own making or translated into Russian.

In practice, the problem is even far more complex. All the texts in the collections of works published abroad were created within other research schools; all of them are a result of previous long-held discussions and thus have their own history and predecessors. Often, this history cannot be read on the collection's pages themselves; it is omitted because professors who use these books in class know the entire material and can always introduce their students to one discussion or another where needed. But we do not feel confident about our Russian colleagues working at all of the specialized faculties being able to deliver the same quality introduction to the anthropology of religion, the anthropology of childhood, the anthropology of migration or epistemology of anthropology (we could go on). Why? One of the reasons is that lack of knowledge of foreign languages is rather a norm than an exception at the majority of Russian anthropology faculties; another reason consists in that a significant 
part of research institutions, including the academic Institute of Ethnology and Anthropology, do not have access to electronic journal databases. Here, however strange it may seem, some Russian universities such as the Higher School of Economics, the Russian State University for the Humanities, Lomonosov Moscow State University, the European University at Saint Petersburg, Tomsk State University, and a few others are well ahead of other, purely research institutions. That said, there is still no institution in Russia that would have access to such a wide and rich variety of journals, books, dissertations, and abstracts that, for example, Max Planck Institute for Social Anthropology (Halle/Saale, Germany) has at its disposal. Our colleagues who work at this institute can at any time access thirty-four electronic databases on anthropology literature of the broadest spectrum possible. ${ }^{18}$

We think that it is only issuing additional funding to help provide access to the research literature but also having the time needed for researchers to read this literature on a regular basis that can definitely change the current situation for the better in the foreseeable future.

\section{JOURNALS}

One of the most important, if not crucial, indicators of a researcher's success is without doubt his or her publication activity, which directly depends on the availability of professional journals. If only two and a half decades ago Sovetskaia etnografiia / Etnograficheskoe obozrenie was the only professional journal for Russian ethnographers to publish in, along with such journals as Vostok (East), Slavianovedenie (Slavic Studies) or, say, Chelovek (Man), which also accepted some anthropological/ethnographic articles, today the number of more or less anthropology-related journals has grown at least five times, and it is hardly possible to try and list all of the journals which in principle accept anthropological works for publication (especially taking into account the unimaginable number of all kinds of Vestnik (Bulletins), Trudy (Works), and Uchenye zapiski (Scholarly Notes), released at different universities and pedagogical institutes.

The growth in the number of specialized journals is an obvious achievement of the post-Soviet development of anthropology. However, now we are faced with another serious issue - that of quality of these journals. It is no secret that the introduction of the so-called list of journals (to publish in for those seeking higher academic degrees) by the Higher Attestation Commission of the Russian Ministry of Education entailed the creation of many new journals which accept literally everything for publication, and so researchers who pur- 
sue the academic degrees of Candidate of Sciences or Doctor of Sciences have the opportunity to publish three of four or even fifteen to twenty 'academic' papers within the space of one year, right in the run-up to the defence of their dissertations. It is, though, beyond the limits of the possible to find examples of serious researchers in anthropology being able to publish such a big number of respectable articles (if to leave out overviews and reviews) outside this vicious system over the same period of time. Why is this possible in Russia? The key to this 'success' is the local character (local journals) ${ }^{19}$ of many of the Russian journals. So the journals often find themselves to be 'at the service' of institutional interests and place on their editorial boards professors and other teaching staff of the university or faculty at which they are issued. They allow themselves to publish articles written by almost exclusively by their 'own' staff and, finally, they either do not peer-review these articles of their 'own' authors or review them by themselves as a formality.

A look at the authors' names featured even in the most well-known Russian anthropological/ethnological journals and, more specifically, in Etnograficheskoe obozrenie ${ }^{20}$ allows us to see that all of them are at best 'national', not 'international'. This fact has its impact on the reputation of these journals and interest in the articles published by them.

Speaking further of the international profile of journals, it is worth paying attention to one more important aspect, namely, their presence (or in the case of Russian journals, rather, non-presence) in the largest international journal databases and/or indexing systems. As a result of purely administrative effort undertaken by academia's managers to find a way of assessing the quality of research in the social sciences and humanities, the inclusion of journals in databases such as Web of Science, Scopus, and, probably, also Springer was prioritized, whereas a database such as ERIH (currently called ERIH PLUS European Reference Index for the Humanities and Social Sciences) was at first ignored, and another huge database - EBSCOhost, Scopus's direct partner, continues to be ignored as of today.

The inclusion or non-inclusion (or, often, editorial board's conscious abstention from trying to get their journal included) of a given journal in one of the mentioned databases or indexing systems, as our colleagues would well know, cannot be considered the only criterion for assessing the quality of this journal, and, by extension, of the texts published in it (for more see Funk 2016: 8-26). However, with academia's managers forcing scholars to play by their own rules, we have to take into account this criterion as well. In the case of Russian journals, the picture is not quite optimistic. As of 2016, among professional anthropological journals, only three Russian journals were indexed in Scopus $^{21}$ - Siberian Historical Research (Q3, SJR 0.195), Social Evolution and 
History (Q3, SJR 0.157), and Etnograficheskoe obozrenie (Q4, SJR 0.112), occupying the $163 \mathrm{rd}, 184 \mathrm{th}$, and $243 \mathrm{rd}$ lines out of 315 . It is hardly worth saying that out of seventy-nine journals in the Q1, only fifteen are issued outside of the US and UK. So anthropology remains a science whose lingua franca is English.

We find it difficult to foresee how fast (if at all) the current state of affairs can be altered. One way could be to try and solve the problems by administrative means, and there is an example of this, namely the creation of a separate subgroup of Russian journals (currently 635!) - the RSCI, Russian Science Citation Index - based on the Web of Science platform. Another way, though, could be to simply start forming international editorial boards for Russian journals, and seeking the broadest authorship possible, while using the widely recognized principle of double blind peer-review. Given this is done, the recognition of Russian journals, along with their inclusion in the best international databases and indexing systems, will undoubtedly follow.

\section{CONCLUDING REMARKS}

The picture we have presented above seems to be rather gloomy. At times, though, such a perspective, somewhat more dramatic on purpose, is necessary in order to fully realize the scale of what needs to be done. The issues raised in this article do not exhaust all the weaknesses of Russian anthropology/ ethnology, and certainly they are not unique to this discipline, at least in the post-Soviet space.

We hope that here we managed to offer some food for thought and further discussion among our colleagues: through our intellectual exchange and joint efforts it would be much easier to state problems and find solutions thereto.

\section{ACKNOWLEDGEMENTS}

The article is written within the framework of the project, entitled "Man in a changing world. Identity and social adaptation: Past and present" (Russian government grant \# 14.B25.31.0009). 


\section{NOTES}

1 The article draws on the theses put forward by Dmitriy Funk at the session of the Division of Historical and Philological Sciences of the Russian Academy of Sciences, held in Moscow on December 16, 2014, and at the 11th Congress of Russian Anthropologists and Ethnologists, held in Yekaterinburg on July 2, 2015 (Funk 2015: 38-44). It is also based on the authors' joint presentation at the international conference "Science of the future", held in Kazan on September 21, 2016 (Funk \& Nam 2016: 134-136).

2 The specialty "Ethnography, ethnology, and anthropology" studies the history and contemporary state of mankind in the form of its specific groups - ethnoses - in the territory of the oecumene (the Earth's inhabited space) and at all stages of its evolution. Ethnoses (ethnic communities, i.e., tribes, peoples, nations, ethnic minorities, and suchlike groups) are social associations comprising many components and having a complex internal structure. Ethnoses and their groups can be studied both as a whole and in terms of their components (language, environment, cultures, everyday life, consciousness and self-consciousness); as an ethnos is in essence fragments of the society (per se), research into it is distinctly multi-sided (http://vak.ed.gov.ru/docume nts/10179/2327517/07.00.07+\%D0\%AD\%D1\%82\%D0\%BD\%D0\%BE\%D0\%B3\%D1\%8 $0 \% \mathrm{D} 0 \% \mathrm{~B} 0 \% \mathrm{D} 1 \% 84 \% \mathrm{D} 0 \% \mathrm{~B} 8 \% \mathrm{D} 1 \% 8 \mathrm{~F} \% 2 \mathrm{C} \% 20 \% \mathrm{D} 1 \% 8 \mathrm{D} \% \mathrm{D} 1 \% 82 \% \mathrm{D} 0 \% \mathrm{BD} \% \mathrm{D} 0 \% \mathrm{BE}$ $\% \mathrm{D} 0 \% \mathrm{BB} \% \mathrm{D} 0 \% \mathrm{BE} \% \mathrm{D} 0 \% \mathrm{~B} 3 \% \mathrm{D} 0 \% \mathrm{~B} 8 \% \mathrm{D} 1 \% 8 \mathrm{~F} \% 20 \% \mathrm{D} 0 \% \mathrm{~B} 8 \% 20 \% \mathrm{D} 0 \% \mathrm{~B} 0 \% \mathrm{D} 0 \% \mathrm{BD} \%$ $\mathrm{D} 1 \% 82 \% \mathrm{D} 1 \% 80 \% \mathrm{D} 0 \% \mathrm{BE} \% \mathrm{D} 0 \% \mathrm{BF} \% \mathrm{D} 0 \% \mathrm{BE} \% \mathrm{D} 0 \% \mathrm{BB} \% \mathrm{D} 0 \% \mathrm{BE} \% \mathrm{D} 0 \% \mathrm{~B} 3 \% \mathrm{D} 0 \% \mathrm{~B} 8 \%$ D1\%8F.doc/10abc054-814a-4460-8071-3ea4a81121f9).

3 From 1995 to 2008 the Faculty of Ethnology. See https://eu.spb.ru/anthropology/about.

4 See http://history.spbu.ru/etnogr-o-kafedre.html. The master programme "Ethnological inspection" was accredited here in 2014 but in general this department has a long history of educating students of ethnology, from the time when - after a fifteen-year break - ethnographic education was resumed at the university in 1967.

5 From 1990 almost up until the end of 2001 the Department of Ethnology and Specific Historical Disciplines.

6 See http://www.hist.igni.urfu.ru/kafedra/client/text.asp?aid=23\&np=1\&ns=1, last accessed on November 21, 2017.

7 See https://vladivostok.postupi.online/vuz/dvfu/programma-magistr/4514/, last accessed on November 21, 2017.

8 Seehttps://www.rsuh.ru/education/section_228/section_289/, last accessed on November 21, 2017.

9 See http://kpfu.ru/imoiv/struktura/otdeleniya/vysshaya-shkola-inostrannyh-yazykovi-perevoda/kafedra-arheologii-i-etnologii, last accessed on November 21, 2017.

${ }^{10}$ See http://ethnography.omskreg.ru/, last accessed on November 21, 2017.

${ }^{11}$ See http://sar.tsu.ru/en/, last accessed on November 21, 2017.

${ }^{12}$ See http://soc.spbu.ru/fakultet/departments/antropol/, last accessed on November 21, 2017. 
${ }^{13}$ See http://anthrop.bio.msu.ru/, last accessed on November 21, 2017.

${ }^{14}$ See http://hist.msu.ru/departments/4011/, last accessed on November 21, 2017.

${ }^{15}$ See http://bgiik.ru/73, last accessed on November 21, 2017.

${ }^{16}$ See http://oreluniver.ru/edustruc/chair/279, last accessed on November 21, 2017.

${ }^{17}$ See http://eu.wiley.com/WileyCDA/Section/id-351621.html?filter=TEXTBOOK, last accessed on November 21, 2017.

18 The information (as of January 2014) was kindly provided by the staff at the Library of Max Planck Institute for Social Anthropology.

${ }^{19}$ In this case, we refer to the criteria for journals used by ERIH PLUS (https://dbh.nsd. uib.no/publiseringskanaler/erihplus/about/approval_procedures):

- Authorship is international when less than two thirds of the authors published in the journal are from the same country;

- Authorship is national when more than two thirds of the authors published in the journal are from the same country;

- Authorship is local when more than two thirds of the authors published in the journal are from the same institution.

${ }^{20}$ See http://journal.iea.ras.ru/, last accessed on November 21, 2017.

${ }^{21}$ See http://scimagojr.com/journalrank.php?category=3314\&area=3300, last accessed on November 21, 2017.

\section{REFERENCES}

Arutiunov, Sergei 1993. Preodolenie kakogo krizisa? [Overcoming What Crisis?] Etnograficheskoe obozrenie, No. 1, pp. 8-14. Available at http://journal.iea.ras. ru/archive/1990s/1993/1.htm, last accessed on November 22, 2017.

Barnard, Alan 2009. Sotsial'naia antropologiia: Issleduia sotsial'nuiu zhizn' liudei. [Social Anthropology: Investigating Human Social Life.]. Moscow: Institut etnologii i antropologii RAN.

Basilov, Vladimir 1992. Etnografiia: est' li u nee budushchee? [Ethnography: Is There Any Future?] Etnograficheskoe obozrenie, No. 4. pp. 3-17.

Basilov, Vladimir 1998. Traditsii otechestvennoi etnografii. [Traditions of National Ethnography.] Etnograficheskoe obozrenie, No. 2, pp. 18-45.

Elfimov, Aleksei (ed.) 2005. Distsiplina i obshchestvo: natsional'nye traditsii. [Discipline and Society: National Traditions.] Etnograficheskoe obozrenie, No. 2, pp. 4-101. Available at http://journal.iea.ras.ru/archive/2000s/2005/2.htm, last accessed on November 22, 2017.

Elfimov, Aleksei (ed.) 2012. Antropologicheskie traditsii: Stili, stereotipy, paradigmy. [Anthropological Traditions: Styles, Stereotypes, Paradigms.] Moscow: Novoe literaturnoe obozrenie. 
Eriksen, Tomas Hilland 2014. Chto takoe antropologiia? [What Is Anthropology?] Moscow: Izdatel'skii dom Vysshei shkoly ekonomiki. Available at http://www. netcabinet.ru/uploads/8/5/0/9/8509295/chto_takoe_antropologia.pdf, last accessed on November 22, 2017.

Funk, Dmitrii 2014. Obsuzhdenie perspektiv razvitiia kafedry etnologii MGU. [Discussing the Development Prospects of the Department of Ethnology of the MSU.] Istoricheskii zhurnal: Nauchnye issledovaniia, No. 1, pp. 93-102. DOI: 10.7256/2222-1972.2014.1.12191.

Funk, Dmitrii 2015. Ob itogakh i problemakh sovremennykh transformatsii etnologii/ antropologii v Rossii. [On the Outcomes and Problems of Modern Transformations in Ethnology/Anthropology in Russia.] In: V. Tishkov \& A. Golovnev (eds.) XI Kongress antropologov i etnologov Rossii: Sb. materialov. Ekaterinburg, 2-5 iiulia $2015 \mathrm{~g}$. Moscow \& Ekaterinburg: IEA RAN \& IIiA UrO RAN, pp. 38-44.

Funk, Dmitrii 2016. Naukometriia v otsenke kachestva publikatsii v sotsial'nykh i gumanitarnykh naukakh. [Scientometrics and Evaluation of Publications in Social Sciences and Humanities.] Sibirskie istoricheskie issledovaniia / Siberian Historical Research, No. 1, pp. 8-26. DOI: 10.17223/2312461X/11/2.

Funk, Dmitri \& Nam, Irina 2016. Identifying Social Anthropology within the Russian University System: The Case of Tomsk. Science of the Future: Proceedings of the Conference - Kazan 2016 (Kazan, September 20-23, 2016). Moscow: Inconsult, pp. 134-136. Available at http://sf-conf.com/assets/files/Proceedings-of-theconference2016.pdf, last accessed on November 22, 2107.

Karlov, Viktor 2000. Etnonatsional'naia refleksiia i predmet etnologii (k probleme samosoznaniia nauki). [Ethnonational Reflection and the Research Focus of Ethnology (toward the Issue of Self-Consciousness of Science).] Etnograficheskoe obozrenie, No. 4, pp. 3-21. Available at http://journal.iea.ras.ru/archive/2000s/2000/4. htm, last accessed on November 22, 2107.

Kon, Igor 1993. Nesvoevremennye razmyshleniia na aktual'nye temy. [Untimely Thoughts on Pressing Topics.] Etnograficheskoe obozrenie, No. 1, pp. 3-8. Available at http:// journal.iea.ras.ru/archive/1990s/1993/1.htm, last accessed on November 22, 2017.

Markov, Gennadii 1992. O bednoi nauke zamolvim slovo. [Let us Support the Poor Science.] Etnograficheskoe obozrenie, No. 5, pp. 3-7.

Semenov, Iurii 1998. Predmet etnografii (etnologii) i osnovnye sostavliaiushchie ee nauchnye distsipliny. [The Research Focus of Ethnography (Ethnology) and Its Main Constituent Disciplines.] Etnograficheskoe obozrenie, No. 2, pp. 3-17.

Shnirelman, Viktor 1992. Nauka v usloviiakh totalitarizma. [Science under Totalitarianism.] Etnograficheskoe obozrenie, No. 5, pp. 7-18.

Sokolovskiy 1993 = Sokolovskii, Sergei. Etnograficheskie issledovaniia: ideal i deistvitel'nost'. [Ethnographic Research: Ideal and Reality.] Etnograficheskoe obozrenie, No. 2, pp. 3-13; No. 3, pp. 3-14.

Sokolovskiy 2003 = Sokolovskii, Sergei. Chetvert'veka rossiiskoi antropologii: 1975-2000. [A Quarter of a Century of Russian Anthropology: 1975-2000.] In: A. Piskoppel et al. (eds.) Etnometodologiia: problemy, podkhody, kontseptsii. [Ethnomethodology: Problems, Approaches, Concepts.] Moscow: Rossiiskii nauchno-issledovatel'skii institut kul'turnogo i prirodnogo naslediia, pp. 136-159. Available at http://old. iea.ras.ru/publications_new/ethnomethodology/pdf/em-9/136-159.pdf. 
Sokolovskiy 2009 = Sokolovskii, Sergei. Rossiiskaia antropologiia: illiuziia blagopoluchiia. [Russian Anthropology: An Illusion of Wellbeing.] Neprikosnovennyi zapas, No. 1, pp. 45-64. Available at http://magazines.russ.ru/nz/2009/1/s4.html, last accessed on November 23, 2017.

Sokolovskiy 2011 = Sokolovskii, Sergei. V tseitnote: zametki o sostoianii rossiiskoi antropologii. [In a Zeitnot: Notes on the State of Russian Anthropology.] Laboratorium: Zhurnal sotsial'nykh issledovanii, No. 2, pp. 70-89. Available at https://cyberleninka.ru/ article/v/v-tseytnote-zametki-o-sostoyanii-rossiyskoy-antropologii, last accessed on November 22, 2017.

Tishkov, Valeri 1992. Sovetskaia etnografiia: preodolenie krizisa. [Soviet Ethnography: Overcoming the Crisis.] Etnograficheskoe obozrenie, No. 1, pp. 5-20.

Tishkov, Valeri 2002. Gorizonty rossiiskoi etnologii. K 70-letiiu Instituta etnologii i antropologii RAN. [The Horizons of Russian Ethnology: Published with Regard to the 70th Anniversary of the Institute of Ethnology and Anthropology, Russian Academy of Sciences.] Novaia i noveishaiia istoriia, No. 5, pp. 3-18.

Tishkov, Valeri \& Pivneva, Elena 2010. Etnologicheskie i antropologicheskie issledovaniia v rossiiskoi akademicheskoi nauke. [Ethnological and Anthropological Research in Russian Academic Science.] Novaia i noveishaia istoriia, No. 2. pp. 3-21.

Ventsel, Aimar \& Struchkova, Natalia 2016. Can We Talk about Post-Soviet Science? Folklore: Electronic Journal of Folklore, Vol. 63, pp. 121-126. http://dx.doi. org/10.7592/FEJF2016.63.discussion. 